\title{
Influence of Organizational Competitiveness on the Performance of Manufacturing Micro and Small Enterprises in Kenya
}

\author{
Peter Njuguna Kimemia, Prof. Roselyn W. Gakure, Dr. Gichuhi A. Waititu \\ (Jomo Kenyatta University of Agriculture and Technology, Kenya) \\ (Jomo Kenyatta University of Agriculture and Technology, Kenya) \\ (Jomo Kenyatta University of Agriculture and Technology, Kenya)
}

\begin{abstract}
This study set out to investigate the influence of organizational competitiveness on the performance of manufacturing micro and small enterprises (MSEs) in Kenya. The study used an exploratory research design targeting a population of 2450 MSEs from Kamukunji 'JuaKali' Association, Nairobi Kenya. A random sample of 180 firms returned 175 (97.2\%) valid responses. Survey data was collected with a semi-structured questionnaire through face-to-face interviews. A pilot test on 20 firms helped to improve the instrument while the Principal Component Analysis (PCA) method extracted the factors with reliability cut-off value of 0.70. Factors loadings that were less than 0.40 were discarded. Descriptive statistics presented the responses in means and standard deviations. To sharpen inferences, ordinal regression analysis was performed using the Polytomous Universal Model (PLUM) of SPSS for Windows 19 location-scale model. Response frequencies of firm performance, ordered in 5-part Likert-type categories, were positively skewed, thus, the negative log-log link function was used. Model fitting information provided log likelihood ratio tests for the null hypothesis that the independent variable was statistically equal to zero. The study found that the organizational competitiveness influences firm performance, positively and significantly.
\end{abstract}

Key words: Organizational Competitiveness, Firm Performance, Micro and Small Enterprises, Manufacturing

\section{Introduction}

The importance of micro and small enterprises (MSEs) in contributing to job creation and output growth is now widely accepted in both developed and developing countries. Of interest in this study is the gradual and organic expansion of enterprises from the survival stage of micro and small into medium size through subcontracting. According to Furlan, Grandinetti, and Camuffo (2007), the evolution of subcontracting is partly driven by subcontracting firms' desire for competitiveness. Grossman and Helpman (2005) posit that some firms have gone so far as to become "virtual" manufacturers through subcontracting, owning designs for many products but making almost nothing. As firms subcontract more and more, a 'new firm' emerges where, seemingly, the traditional firm boundaries get increasingly blurred and parent firms move further towards a coordinator role themselves (Grossman \& Helpman, 2005). The new firm leverages more competitive advantage from its core competencies through networking, alliances, partnerships and outsourcing with other firms.

According to OECD (2004) capable MSEs have the opportunity to insert themselves in the global value chain through subcontracting linkages. This behooves MSEs themselves to implement competitive operating practices and business strategies, adjusting and adopting new approaches and inventing new ways of doing things to wade off the danger of losing their existing markets (OECD, 2004). Studies have shown that engagement in subcontracting helps to integrate a firm's resources towards enhancing capabilities, competitive advantage and ultimately improved performance. Gierson and Mead (1995) identified subcontracting as a leading mechanism for establishing efficient business linkages. All businesses that are party to a business linkage relationship must have the capacity to fulfill their obligations and meet client expectations in quantity, quality, timeliness and price (Gierson \& Mead, 1995).

Based on Resource-based View (RBV), Barney (1991) argued that in addition to simply possessing valuable, rare, inimitable and non-substitutable resources, a firm also needs to be organized in such a manner that it can exploit the full potential of those resources if it is to attain organizational competitiveness. Barney (1991) propounds that there is heterogeneity among firms and that it is the deployment of their unique resources that allows them to achieve sustainable competitive advantage. Supporting Barney (1991), Tuan and Mai (2012), posit that the implementation of a competitive advantage strategy facilitates the reduction of costs, the exploitation of market opportunities, and/or neutralization of competitive threats. Following Tuan and Mai (2012), competitive advantages are hence seen through actual implementation of competitive strategy.

Tuan and Mai (2012) applied the Resource-Based View (RBV) and Industrial Organization concept on a firm level analysis of supporting industries in Hanoi City-Vietnam focusing on competitive advantage and organizational capabilities. The dependent variable of the study was firm performance indicated by the 
perceived sales growth over a period of 3 consecutive years while the independent variable(s) were organizational capabilities, competitive advantage and industry effects. Organizational capability and ccompetitive advantage were composite variable consisting of cost leadership, quality, and innovation. A multivariate hierarchical ordered probit regression analysis was used since the dependent variable had ordinal levels. The scholars found that a firm's organizational capabilities contribute to its competitive advantage, in turn affects performance, and mediates the organizational capabilities-performance relationship.

Porter (1980; 1985) suggests low cost leadership, differentiation, and focus (cost and differentiation) are factors that embody the rules of competition and determine industry attractiveness. In line with Porter's (1980, 1985) other scholars concur that close to the generic strategies of cost leadership, differentiation and focus, three quite similar dimensions of cost reduction, quality and innovation are observable to depict the organizational competitiveness (Tuan \& Mai, 2012; Wang \& Ang, 2004). Thus, as suggested in past studies, the most plausible indicators for competitiveness include: (a) cost reduction ( indicated by low-cost materials, lowcost labour, designs to economize on materials, level of capacity utilization, degree of automation, effective sales promotion and execution); (b) quality (indicated by quality through purchased inputs, product engineering skills, strict quality control, identifying and responding to market trends, quality and effectiveness of customer service), and (c) innovation (indicated by purchasing innovation, product engineering, process engineering, marketing) (Porter, 1980; 1985 Tuan \& Takahashi, 2009; Tuan \& Mai, 2012).

Based on other studies (Grant, 2002; Webster et al., 1997; Tuan \& Mai, 2012) organizational competitiveness has a direct link with firm performance. It is, therefore, hypothesized that organizational competitiveness, observed by three parameters, namely: cost reduction, quality and innovation of subcontracting firms have a significant and positive effect on firm performance. This relationship between organizational competitiveness of subcontracting firms and firm performance leads to a testable null hypothesis as follows: -

\section{Hypothesis, $\boldsymbol{H}_{0}$ : Organizational competitiveness has no influence on firm performance.}

Firm performance is grounded in the Goal-Setting Theory (Chong, 2008; Locke \& Latham, 2002). Goal setting is the mechanism by which a firm delivers results against its strategy on the extent to which there is clarity, challenge, commitment, feedback, and task complexity (Locke \& Latham, 2002). Organizational competitiveness was founded on the Resource-based Review (RBV) (Barney, 1991).

\section{Research gap}

There is ample evidence from some countries such as Japan and Taiwan that subcontracting is important in explaining firm performance as posited by Berry (1997) but the existing literature on organizational competitiveness of firms engaging in subcontracting suggest it is seldom examined empirically in Kenya. Therefore, the present study aims to address the question of how organizational competiveness influences the firm performance of subcontracting firms in an attempt to tackle the challenges of MSE growth and inadequate inter-firm linkages focusing on the underperforming manufacturing sector in Kenya. The study focuses on small-small cooperative links as opposed to the asymmetric interaction between large and small firms in light of the bimodal firm distribution and lukewarm commitment of large firms to MSEs, despite various policy emphases. Lack of extant data on organizational competitiveness of firms in subcontracting and lack of information on the key variables that interact to make subcontracting to emerge and/or become effective is not well-documented, thus necessitating the study. Specifically, the study sought to investigate how the organizational competitiveness influences the performance of manufacturing MSEs in Kenya.

\section{Research Methodology}

The overriding purpose of the present study was to establish the influence of organizational competitiveness on the performance of manufacturing micro and small enterprises in Kenya. A model encompassing the hypothesized interaction between the dependent variable and the explanatory variable was constructed. In order to test the null hypothesis, 'Organizational Competitiveness has no Influence on Firm performance', the present study used an exploratory research design. The exploratory method offered the flexibility required in familiarizing with subcontracting and gaining insights about the phenomenon about which little is known among Kenyan manufacturing MSEs (Churchill \& Iacobucci, 2005; Cooper \& Schindler, 2003). The population of study was the manufacturing enterprises in Kamukunji 'JuaKali' Association, Nairobi, Kenya, estimated at 2450. 'Jua Kali' is Kiswahili for 'working under the hot sun'. The rationale for selecting the target population was that it was sufficiently representative of MSE manufacturers in Kenya because it was the most developed in Kenya, with comprehensive official statistics and a regularly updated list of membership. It seemed improbable that the subcontracting phenomenon would be stronger in other undeveloped clusters.

A sample of 180 firms was selected through simple random sampling. Sampling strategies and sampling design are constrained by the practical circumstances surrounding the target population, time and cost. 
The appropriate sample size for the population-based survey was determined largely by three factors: The estimated prevalence of the variable of interest - subcontracting in this instance (estimated at 15\%); The desired level of confidence, 95\% (standard value of 1.96) and; the acceptable margin of error, 5\% (standard value of 0.05). The data relating to perceptions towards firm performance and organizational competitiveness were collected with a semi-structured questionnaire through face-to-face interviews. The questionnaire was administered personally to ensure participation and to enhance response rate. A pilot test on 20 firms helped to remove ambiguities and improve the instrument as well as test for its reliability and validity. Close-ended questions asking respondents to rate various questionnaire items using an 5-part Likert-type ordinal scale representing a spectrum of subjective feelings and opinions with 1 implying the worst (or strong disagreement) and 5 the best (or strong agreement) were employed to solicit specific responses. A few open-ended questions elicited unique answers to general questions.

\section{Data Analysis Procedure}

Data was analyzed with the Polytomous Universal Model (PLUM) function of SPSS for Windows version 19 that utilizes heterogeneous choice (location-scale) models. SPSS PLUM version 19 uses the locationscale terminology for its models, and it also makes it easy to estimate a broad range of models, choose different link functions that may be appropriate for the data and compute other quantities of interest using the cumulative distribution function (CDF) formulation (Norusis, 2012). The algebraic sign of the coefficients was of interest. Researchers suggest the heterogeneous choice (location-scale) models offer superior fit and are more parsimonious and interpretable for ordinal data than those estimated by non-ordinal methods (Allison, 1999; Hoetker, 2004; Williams, 2009).

With the normal distribution, the probability of observing an individual value of $\mathrm{Y}$ is given by the equation: $\operatorname{Prob}(\mathrm{Y}=\mathrm{j})=\Phi\left(\alpha_{\mathrm{j}}-\beta \mathrm{x}\right)-\Phi\left(\alpha_{\mathrm{j}-1}-\beta \mathrm{x}\right)$, where $\Phi()$ denotes the standardized cumulative normal distribution function $(\mathrm{C} D F)$. In order that all the probabilities are positive, we must have: $0<\alpha_{1}<\alpha_{2}<\ldots<\alpha_{\mathrm{j}-1}$. The general cumulative link model is modified to a location-scale link format, thus: $\mathrm{G}(\operatorname{Pr}(\mathrm{Y} \geq \mathrm{i} \mid \mathrm{X}=\mathrm{x}))=$ $-\log (-\log (\operatorname{Pr}(\mathrm{Y} \geq \mathrm{i} \mid \mathrm{X}=\mathrm{x})))=\left(\frac{\alpha_{i}-\beta x}{\exp (\gamma x)}\right), \mathrm{i}=1, \ldots, \mathrm{I}$, where $\mathrm{G}$ is the negative $\log -\log \operatorname{link}$ function, $x$ is a vector of explanatory variables; $\beta$ represents a vector of unknown parameters associated with $x, \alpha_{i}$ are unknown threshold parameters-separating adjacent $\mathrm{Y}$ levels-to be estimated with $\beta$ and $\gamma$ is the scale associated with $x$. $\beta x$ in the location component and $\gamma x$ represents the scale.

From the literature, Norusis (2012) points out five different link functions that were available in the Polytomous Universal Model or PLUM Regression procedure in SPSS, namely, the logit, probit, complementary log-log, negative log-log, and inverse Cauchy as shown on Table 1. Norusis (2012) affirms the choice of link function in an ordinal regression analysis should be driven by the distribution of the response or the dependent variable, as in the present study the performance of manufacturing MSEs. The present study used the negative log-log link because the cumulative probability was considered more probable for lower categories, rather than the higher outcome frequencies.

Table 1: Link Functions

\begin{tabular}{lll}
\hline Ordinal Link & Function Form & Typical Application \\
\hline Logit & $\ln \left(\frac{p}{1-p}\right)=\alpha_{i}-\beta x$ & Evenly distributed categories \\
Complementary log-log & $\ln (-\ln (1-p))=\alpha_{i}-\beta x$ & Higher categories more probable \\
Negative log-log & $-\ln (-\ln (p))=\alpha_{i}-\beta x$ & Lower categories more probable \\
Probit & $\Phi^{-1}(p)=\alpha_{i}-\beta x$ & Analyses with explicit normally distributed \\
Cauchit (inverse Cauchy) & $\tan (\pi(p-0.5))=\alpha_{i}-\beta x$ & latent variable \\
\hline
\end{tabular}

\section{Data Interpretation Procedure}

The statistical estimation of the overall model was carried out with the SPSS for Windows Version 19 PLUM, using location-scale model and the negative log-log link function. Model fitting information provided model fitting criteria, likelihood ratio tests (distributed chi-squared), LR $\chi^{2}$, along with the degrees of freedom and probability, $\rho$ values, with significance level set at 0.05 . The log likelihood Chi-square test compared the final model $\left(\mathrm{LL}_{\mathrm{m}}\right)$ and the intercept-only model $\left(\mathrm{LL}_{\mathrm{o}}\right)$ to provide the test of the null hypothesis that the independent variable was statistically equal to zero. The goodness-of-fit statistics, Pearson chi-square, $\chi^{2}$, and the Deviance chi-square, with their observed significance levels tested the null hypothesis that the model fits the data at the set 0.05 significance level. The coefficient of determination, Pseudo R-Square, $\mathrm{R}^{2}$, summarized the 
proportion of variance (Nagelkerke, $\mathrm{R}^{2}$ ) in the dependent variable, FPERF that could be accounted for individually by ORGCO. The parameter estimates table indicated where the individual respondents placed their firm performance in the ordinal 5-point Likert categories coded 1 to 5, and gave the thresholds of the ordinal categories, the coefficients (both location and scale), their standard errors, Wald test statistic with associated degrees of freedom and significance levels ( $\rho$ values or sig.), and the $95 \%$ confidence interval of the coefficients. The likelihood ratio test was the one used to test whether the inclusion of a variable in the locationscale equations did or did not significantly improve model fit while the direction of relationship was provided by the algebraic sign of the coefficient (Norusis, 2012; Allison, 1999; Hoetker, 2004; Williams, 2009).

\section{Validity, Reliability and Factor Analyses for Study Variables}

Validity, reliability and factor analyses tests were conducted on the data collection instrument comprising all items in the respective variables and their subscales, as compiled from the literature review and pilot test, was considered. Principal Component Analysis (PCA) method was used to extract the factors. The criteria states, as suggested by some scholars (George \& Mallery, 2003; Hair et al., 2010), that Cronbach's Alpha of a scale should be greater than 0.70 for items to be used together as a scale while factor loadings greater than 0.40 are considered statistically significant for studies with sample size less than 200 . Therefore, in the present study, \pm 0.40 was used as the cut-off for loadings since the sample size of the study was 180 . The higher the factor loadings were the closer they were related to the variable.

\section{(i) Firm Performance}

Firm performance was the dependent variable in the present study and in accordance with the literature, a combination of both financial and non-financial indicators led to a balanced performance measurement. The financial indicators were: (i) sales growth (ii) growth in profits(iii) change in of assets by gross value plant and machinery; (iv) return on assets to measure capital efficiency. The non-financial indicators were (i) growth in market share; (ii) product success; (iii) increase in number of employees and; (iv) labour productivity (Tuan \& Yoshi, 2010, Kongmanila \& Takahashi, 2009; Hu, Zheng, \& Wang, 2011; Marimuthu, Arokiasamy, \& Ismail, 2009; Ong'onga \& Abeka, 2011). Likert-type scales can elicit responses assessed as the perceived performance relative to competitors' treated as ordinal under the assumption that the levels of firm performance status have five-point ordering ( 1 ="Significantly decreased" to $5=$ "Significantly increased"),

Firm performance measures had a total of 8 items generated from literature comprising both the financial and non-financial indicators. The results indicated that with factor loadings of between .695 and .9 , the construct of the 8 measurement items was valid for firm performance. The Cronbach's Alpha coefficient for the 8 items was $\alpha=0.921$, which means the instrument had an excellent level of consistency, and fit for use in data collection.

Table 2: Factor Analysis for Firm Performance

\begin{tabular}{|c|c|}
\hline Items & Factor Loading \\
\hline \multicolumn{2}{|l|}{ Financial } \\
\hline 1. Growth in sales (volume) & .900 \\
\hline 2. Growth in profit & .881 \\
\hline 3. Gross value of capital(machinery) & .808 \\
\hline 4. Return on assets & .779 \\
\hline \multicolumn{2}{|l|}{ Non-financial } \\
\hline 5. Growth in market share & .871 \\
\hline 6. Product success & .760 \\
\hline 7. Labour productivity & .708 \\
\hline 8. Increase in workers & .695 \\
\hline No. of items & 8 \\
\hline Cronbach's Alpha & .921 \\
\hline
\end{tabular}

\section{(ii) Organizational competitiveness}

In order to test the validity and reliability of organizational competitiveness, an instrument comprising 15 items was considered as originally compiled from the literature. Subsequently, 3 items with low factor loadings were discarded, leaving 12 items with factor loadings of between .436 and .788. A high internal consistency for the survey was demonstrated based on the Cronbach Alpha of $\alpha=0.844$ for all the 12 items. 
Table 3: Factor Analysis for Organizational Competitiveness

\begin{tabular}{|c|c|}
\hline Factor & Factor Loading \\
\hline \multicolumn{2}{|l|}{ Cost reduction } \\
\hline 1. Effective sales promotion and Execution & .646 \\
\hline 2. Low-cost labor & .553 \\
\hline 3. Level of capacity utilization & .507 \\
\hline 4. Low-cost materials & .325 \\
\hline 5. Degree of automation & .252 \\
\hline 6. Designs to economize on materials & .206 \\
\hline \multicolumn{2}{|l|}{ Quality } \\
\hline 7. Quality and effectiveness of customer service & .788 \\
\hline 8. Identifying and responding to market trends & .631 \\
\hline 9. Through purchased inputs, & .595 \\
\hline 10. Product engineering skills & .490 \\
\hline 11. Strict quality control & .436 \\
\hline \multicolumn{2}{|l|}{ Innovation } \\
\hline 12. Product engineering & .745 \\
\hline 13. Purchasing innovation & .744 \\
\hline 14. Process engineering & .567 \\
\hline \multirow{3}{*}{$\begin{array}{l}\text { 15. Marketing } \\
\text { No. Of items } \\
\text { Cronbach's Alpha }\end{array}$} & .465 \\
\hline & 12 \\
\hline & .844 \\
\hline
\end{tabular}

NB: The shaded factors were eliminated

\section{Description of Respondents}

Out of the 180 questionnaires administered, 175 (97.2\%) were considered valid, with no missing data. The response rate of $97.2 \%$ was, therefore, considered adequate for the study according to Mugenda and Mugenda (2003). The targeted enterprises were aged 11.5 years for the firms and 33.74 years for the owner/managers on average. About $92 \%$ of the firms were managed by men. The preliminary findings showed $75.4 \%$ of the respondents had attained primary level and below and $95.4 \%$ had attained product related skills training through apprenticeship and learning on the job. The uppermost manufactured products were metallic wood stoves $(58.9 \%)$ and metallic boxes $(36.0 \%)$ in a range of 24 different products. Regarding subcontracting practice which was the subject of the present study, $97.1 \%$ offered subcontracts. When asked about the importance of business partners by size, $94.3 \%$ of the respondents ranked other small firms above average as compared to $50.9 \%$ who regarded the large firms' importance as above average.

The respondents were presented with a list of six factors and asked a YES/NO question on what they thought were the reason(s) their subcontracting partners had retained them as subcontracting partners. A huge majority (92.6\%) viewed good quality of their products as the uppermost factor. The other factors in descending relative importance include: Personal networking (64.6\%), delivery efficiency (60.0\%), location (54.3\%), cheap/low prices $(24.6 \%)$ and inherent capabilities (2.3\%). The results affirmed Berry (1997) that diverse forces are at play in building up firm competitiveness, underpinning the importance of proving oneself as a reliable partner. Deeper factors than the traditional 'low road' strategies of cheap products or low price are at work in transforming capabilities into comparative advantage in the subcontracting relationships. 'High road' competitive strategies of quality efficiency, flexibility and maintaining a good relationship with others are of essence.

\section{a. Firm Performance}

\section{Data Analysis of Study Variables}

Firm performance, the dependent variable in the present study, was measured in both financial and nonfinancial indicators and treated as ordinal under the assumption that the levels of firm performance status have five-point ordering. The respondents were asked to evaluate their firm's performance by rating various indicators of their business operations in the last five consecutive years on a scale of 1 to 5 , where 1 represented 'significantly decreased' and 5 represented 'significantly increased'. The descriptive results on Table 4 show that $0.8 \%$ of the respondents had experienced significant increase while $39.1 \%$ had seen relative increase in firm 
performance in the last five consecutive years. Additionally, $20.9 \%$ and $0.3 \%$ had experienced relative decrease and significant decrease respectively. The data further show $39 \%$ recorded no change. The overall mean score suggest the majority of the firms showed some increase in performance $(M=3.20, S D=.7)$. The respondents indicated they had achieved highest performance in product success $(M=3.36, S D=.79)$ and least performance in gross value of capital, say machinery $(M=2.98, S D=0.67)$.

The findings corroborated Kinyanjui (2006) that despite so much pooling of dynamism in the Kenyan 'jua kali' sector, some firms do not seem to advance. The study found as expected that MSEs have little capital intensity and invest little in machinery and their strategy in subcontracting could be predominantly geared towards sharing equipment to guarantee short-term product success when they receive orders. It is expected that with low inventories of machinery and tools the spirit of cooperativeness would thrive. The small number of firms that experienced significant increase in performance was indicative of the overall underperformance of the Kenya manufacturing sector as reported in the Kenya Economic Survey 2012 (GOK, 2012).

Table 4: Response Frequencies for Firm performance

\begin{tabular}{|c|c|c|c|c|c|c|c|c|}
\hline Iter & & $\begin{array}{c}\text { Significantly } \\
\text { decreased } \\
1 \\
\end{array}$ & $\begin{array}{c}\text { Relatively } \\
\text { decreased } \\
2 \\
\end{array}$ & $\begin{array}{c}\text { No change } \\
3 \\
\end{array}$ & $\begin{array}{c}\text { Relatively } \\
\text { increased } \\
4 \\
\end{array}$ & $\begin{array}{c}\text { Significantly } \\
\text { increased } \\
5 \\
\end{array}$ & $\begin{array}{c}\text { Mean } \\
M \\
\end{array}$ & 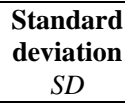 \\
\hline \multicolumn{9}{|c|}{ Firm Performance } \\
\hline \multicolumn{9}{|c|}{ Financial } \\
\hline & $\begin{array}{l}\text { Growth in sales } \\
\text { (volume) }\end{array}$ & 0.0 & 30.3 & 10.3 & 58.9 & 0.6 & 3.30 & 0.98 \\
\hline 2. & Growth in profit & 1.1 & 29.7 & 16.6 & 52.6 & 0.0 & 3.21 & 0.86 \\
\hline 3. & Return on assets & 0.6 & 21.7 & 53.1 & 24.6 & 0.0 & 3.02 & 0.68 \\
\hline 4. & $\begin{array}{l}\text { Gross value of } \\
\text { capital(machinery) }\end{array}$ & 0.0 & 24.0 & 54.3 & 21.1 & 0.6 & 2.98 & 0.67 \\
\hline Sub & average 1 & 0.4 & 26.4 & 33.6 & 39.3 & 0.3 & 3.13 & 0.67 \\
\hline \multicolumn{9}{|c|}{ Non-financial } \\
\hline 1. & Product success & 0.6 & 12.6 & 39.4 & 45.1 & 2.3 & 3.36 & 0.79 \\
\hline 2. & $\begin{array}{l}\text { Growth in market } \\
\text { share }\end{array}$ & 0.0 & 23.4 & 25.1 & 50.3 & 1.1 & 3.29 & 0.82 \\
\hline 3. & Increase in workers & 0.0 & 10.9 & 53.1 & 35.4 & 0.6 & 3.26 & 0.79 \\
\hline & Labor productivity & 0.0 & 14.3 & 60.0 & 25.1 & 0.6 & 3.12 & 0.77 \\
\hline \multicolumn{2}{|c|}{ Sub-average 2} & 0.2 & 15.3 & 44.4 & 39.0 & 1.2 & 3.26 & 0.74 \\
\hline \multicolumn{2}{|c|}{ Grand average } & 0.3 & 20.9 & 39 & 39.1 & 0.8 & 3.20 & 0.70 \\
\hline
\end{tabular}

\section{i. Distribution of Ordinal Categories of Firm Performance and Choice of Link Function}

Firm performance, FPERF, was treated as ordinal under the assumption that respondents placed themselves in a five point ordering ( 1 = 'significantly decreased' and 5='significantly increased'). Figure 1 depicts the distribution of the different categories of firm performance. The frequencies for the categories of firm performance $0,1,2,3,4$ representing the 5-point Likert scale ( $1=$ "significantly decreased" and 5= "significantly increased") were $21.7 \%, 20 \%, 46.9 \%, 10.9 \%$ and $.6 \%$ respectively. At a glance, Figure 1 shows the ordinal frequencies were positively skewed and clearly shows that lower performance categories were more probable. According to Smith and McKenna (2012), when observations are positively skewed, with about 40\%, $30 \%, 20 \%$ and $10 \%$ of the outcome frequencies appearing on the low to high continuum, the low categories are then considered to be more probable. Checked against Smith and McKenna's (2012) criteria on Table 1 a negative log-log function was imposed as the appropriate link function for the ordinal regression in instances where lower categories are more probable. However, as expected, the frequencies at various adjacent levels differ from the observations made on Table 4, where the performance statuses were placed at $0.3 \%, 20.9 \%$, $39 \%, 39.1 \%$ and $0.8 \%$ for categories $1,2,3,4$, and 5 respectively. The findings agreed with view in literature that in ordinal categories, the distances between adjacent levels are unknown, and it would be naïve to treat ordinal data otherwise (Norusis, 2012; Smith \& McKenna, 2012). 


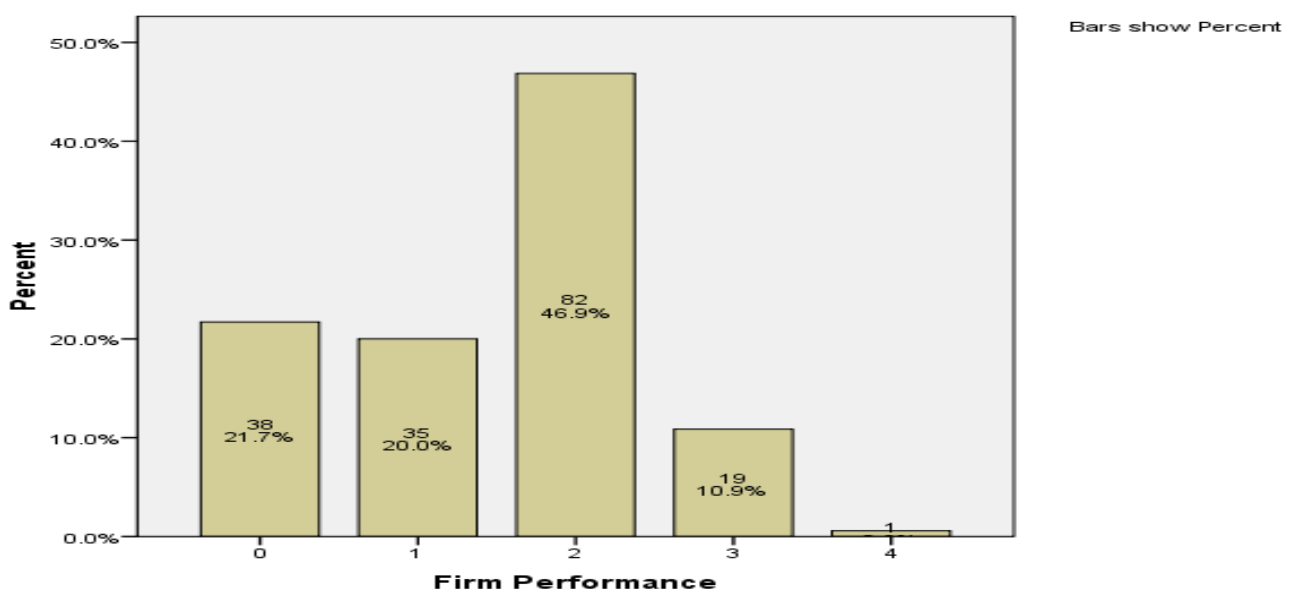

Figure 1: $\quad$ Distribution of Ordinal Categories of Firm Performance

\section{b. Organizational competitiveness}

i) Descriptive Analysis for Organizational competitiveness

The organizational competitiveness in cost leadership, quality, and innovation was accounted for by the presence of at least one factor in each of the three separate scales supportive of competitive advantages: cost leadership, quality, and innovation rated on a five-point Likert scales, 1= "great disadvantage", 5= "great advantage" as suggested by some scholars (Chandler \& Hanks, 1994; Tuan \& Takahashi, 2009; Grant, 2002; Wang \& Ang, 2004). The respondents rated the competitiveness of their firms in comparison with their competitors in same product lines in the last three years on a scale of 1 to 5 , where 1 represents big disadvantage and 5 represents big advantage.

Table 5 presents the descriptive analysis results for organizational competitiveness. The competitiveness was indicated by fifteen measures were grouped into three categories as cost reduction, quality or innovation. The results on Table 5 show $1.2 \%$ had the opinion they were at a great disadvantage, $8.3 \%$ had a small disadvantage, $59.3 \%$ had neither disadvantage nor advantage while $29.6 \%$ had a small advantage and $1.5 \%$ a big advantage. In comparative terms, the results on Table 5 showed the overall mean score for organizational competitiveness was $3.22(S D=0.38)$, falling in the small advantage region. The mean scores for the sub-scales were: cost-reduction $(M=3.19, S D=0.75)$, quality $(M=3.27, S D=0.79)$, and innovation $(M=3.20$, $S D=0.83$ ). The study shows the firms perceived themselves to have an above average competiveness, with quality being the most important aspect of competitiveness.

The results further indicate the firms had highest scores in the factors that were assumed critical to their competitiveness. The uppermost factors were: Quality and effectiveness of customer service $(M=3.57$, $S D=0.79)$; Marketing $(M=3.56, S D=0.93)$; Identifying and responding to market trends $(M=3.50, S D=0.98)$ Effective sales promotion and execution $(M=3.36, S D=0.82)$; Low-cost labor $(M=3.34, S D=0.81)$. Based on the survey data, this study concurred with past studies that organizational competitiveness in subcontracting is a leading mechanism for deploying capacity to meet client expectations. Ultimately firms improve performance through win-win linkages manifested in marketing, customer service, and quality, responsiveness to market trends, sales promotion, and low cost labour. Tuan and Mai (2012) focusing on competitive advantage as a composite variable comprising cost leadership, quality, and innovation affirm that organizational capabilities influences performance. Thus, that firm that has enhanced organizational capabilities and is party to business linkages possesses the capacity to fulfill its obligations and ultimately improves performance.

Table 5: $\quad$ Response Frequencies for Organizational Competitiveness

\begin{tabular}{|c|c|c|c|c|c|c|c|c|}
\hline \multirow{2}{*}{\multicolumn{2}{|c|}{ Item }} & $\begin{array}{l}\text { Big } \\
\text { Disadvantage }\end{array}$ & $\begin{array}{l}\text { Small } \\
\text { Disadvantage }\end{array}$ & Neutral & $\begin{array}{l}\text { Small } \\
\text { advantage }\end{array}$ & $\begin{array}{l}\text { Big } \\
\text { advantage }\end{array}$ & Mean & $\begin{array}{l}\text { Square } \\
\text { deviation }\end{array}$ \\
\hline & & 1 & 2 & 3 & 4 & 5 & $M$ & $S D$ \\
\hline \multicolumn{9}{|c|}{ Cost reduction } \\
\hline 1. & Low-cost labor & 0.0 & 6.9 & 54.3 & 37.1 & 1.7 & 3.34 & 0.81 \\
\hline 2. & Level of capacity utilization & 1.7 & 17.1 & 73.7 & 7.4 & 0.0 & 2.87 & 0.93 \\
\hline 3. & $\begin{array}{l}\text { Effective sales promotion } \\
\text { and Execution }\end{array}$ & 0.0 & 9.7 & 45.7 & 43.4 & 1.1 & 3.36 & 0.82 \\
\hline \multicolumn{2}{|c|}{ Sub-Average 1} & 0.6 & 11.2 & 57.9 & 29.3 & 0.9 & 3.19 & 0.75 \\
\hline
\end{tabular}




\begin{tabular}{|c|c|c|c|c|c|c|c|c|}
\hline Item & & $\begin{array}{l}\text { Big } \\
\text { Disadvantage }\end{array}$ & $\begin{array}{l}\text { Small } \\
\text { Disadvantage }\end{array}$ & Neutral & $\begin{array}{l}\text { Small } \\
\text { advantage }\end{array}$ & $\begin{array}{l}\text { Big } \\
\text { advantage }\end{array}$ & Mean & $\begin{array}{l}\text { Square } \\
\text { deviation }\end{array}$ \\
\hline \multicolumn{9}{|c|}{ Quality } \\
\hline 4. & Through purchased inputs & 1.1 & 9.1 & 56.0 & 33.7 & 0.0 & 3.22 & 0.81 \\
\hline 5. & Product engineering skills & 1.1 & 6.3 & 87.4 & 5.1 & 0.0 & 2.96 & 1.14 \\
\hline 6. & Strict quality control & 0.0 & 6.3 & 80.6 & 13.1 & 0.0 & 3.07 & 1.03 \\
\hline & $\begin{array}{l}\text { Identifying and responding } \\
\text { to market trends }\end{array}$ & 0.6 & 7.4 & 33.7 & 57.1 & 1.1 & 3.50 & 0.98 \\
\hline & $\begin{array}{l}\text { Quality and effectiveness of } \\
\text { customer service }\end{array}$ & 1.7 & 9.7 & 28.6 & 50.3 & 9.7 & 3.57 & 0.79 \\
\hline Sub- & Average 2 & 0.9 & 7.8 & 57.3 & 31.9 & 2.2 & 3.27 & 0.79 \\
\hline \multicolumn{9}{|c|}{ Innovation } \\
\hline 9. & Purchasing innovation & 2.9 & 9.1 & 50.3 & 37.1 & 0.6 & 3.23 & 0.78 \\
\hline & Product engineering & 3.4 & 8.0 & 75.4 & 12.6 & 0.6 & 2.99 & 0.95 \\
\hline 11. & Process engineering & 1.7 & 5.1 & 83.4 & 9.1 & 0.6 & 3.02 & 1.07 \\
\hline 12. & Marketing & 0.6 & 1.7 & 42.3 & 52.0 & 3.4 & 3.56 & 0.93 \\
\hline$S u b$ & Average 3 & 2.2 & 6.0 & 62.9 & 27.7 & 1.3 & 3.20 & 0.83 \\
\hline Gra & d Average & 1.2 & 8.3 & 59.3 & 29.6 & 1.5 & 3.22 & 0.78 \\
\hline
\end{tabular}

\section{(ii) Inferential Analysis for Organizational Competitiveness}

Figure 2 shows the relationship that existed between organizational competitiveness (ORGCO) and firm performance (FPERF). As expected, the relationship was non-linear. The Model Fitting Information on Table 6 show organizational competitiveness was statistically and significantly different from zero and the final the model with ORGCO was an improvement to the model with intercept only, $\operatorname{LR} \chi^{2}(2,175)=11.701, p=0.003$, which was significant at 0.05 level. The goodness-of-fit statistics, Pearson Chi-Square, $\chi^{2}$, tested whether the observed data were consistent with the fitted model. The null hypothesis was that the model fitted the data well meaning if the $\rho$ values were greater than .05 for both $\chi^{2}$ and $\mathrm{D}$ then the model does fitted the data well. From the results, the model with organizational competiveness fitted the data well, since $\chi^{2}$ was large, and non-significant, $\chi^{2}=504.684, d f=610$, sig. $=1.000$.

The coefficient of determination, Pseudo R-Square, $\mathrm{R}^{2}$, summarized the proportion of variance (Nagelkerke, $\mathrm{R}^{2}=$ $7.0 \%$ ) in the dependent variable, FPERF, that could be accounted for individually by ORGCO. The Nagelkerke, $\mathrm{R}^{2}$ of 0.070 suggest that individually, ORGCO explained $7 \%$ variance in firm performance, FPERF. On the overall, since the likelihood ratio Chi-square test showed ORGCO was significant, $\operatorname{LR} \chi^{2}(2,175)=11.701, p=0.003$, only the algebraic sign of the location coefficient was of interest from the parameter estimates in Table 7. SPSS PLUM models the cumulative distribution function $(C D F)$ of the response from the "bottom up" or in ascending order. This parameterization meant that a negative value of the regression coefficient was associated with higher predicted probabilities of being in higher performance response categories. Therefore, the interpretation was that for a one unit increase in ORGCO, FPERF was expected to change by .106 while the other variables were held constant $(\beta=-.106)$. The null hypothesis 'organizational competitiveness has no influence on firm performance' was therefore rejected.

The study findings indicated that the model with ORGCO is significantly different from the intercept only model; meaning there is a significant effect for organizational competitiveness on firm performance. According to Tuan and Takahashi (2009), organizational competitiveness factorized into cost reduction, quality and innovation has direct and positive influence on performance. Therefore, the current study corroborates the previous findings in literature. The descriptive results showed most of the firms put greater emphasis on the cost reduction strategy than on innovation and quality. The findings corroborated Berry (1997) that most MSEs travel the traditional 'low road' of cheap products or low price strategies and not the 'high road' of quality, efficiency and flexibility through innovation that make for a more complete sustainable strategy to improve firm performance. 


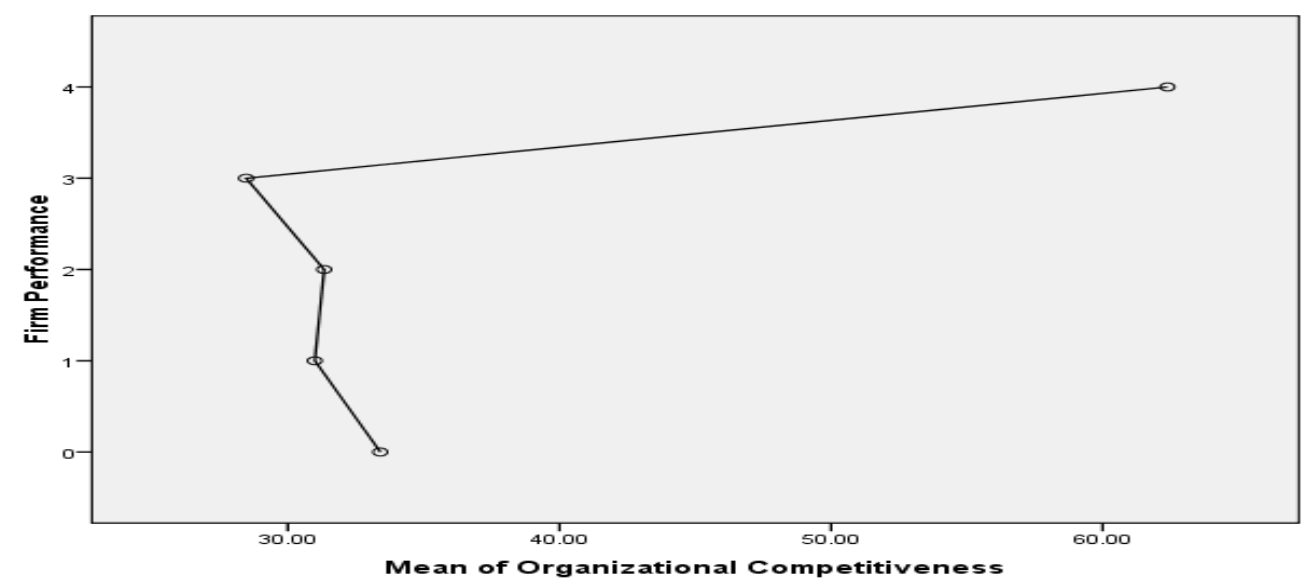

Figure 2: Relationship of Organizational Competitiveness and Firm Performance

Table 6: Model Fitting for Organizational Competitiveness

\begin{tabular}{lccc} 
Model Fitting Information & & & \\
\hline Model & $\mathbf{- 2}$ Log Likelihood & Chi-Square & Sig. \\
\hline Intercept only & 436.428 & & \\
Final & 424.727 & 11.701 & 2 \\
\hline
\end{tabular}

\begin{tabular}{|c|c|c|c|}
\hline 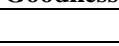 & Chi-Square & $d f$ & Sig. \\
\hline Pearson & 504.684 & 610 & .999 \\
\hline Deviance & 415.598 & 610 & 1.000 \\
\hline
\end{tabular}

Pseudo R-Square

\begin{tabular}{lc}
\hline Analog & Value \\
\hline Cox and Snell & .065 \\
Nagelkerke & .070 \\
McFadden & .026 \\
\hline Linkfun
\end{tabular}

Link function: Negative Log-log.

Table 7: Parameter Estimates for Organizational Competitiveness Parameter Estimates

\begin{tabular}{llrrrrrrr}
\hline & & & & & & \multicolumn{3}{c}{ 95\% Confidence Interval } \\
\cline { 6 - 9 } & & Estimate & Std. Error & Wald & $d f$ & Sig. & Lower Bound & Upper Bound \\
\hline Threshold & {$[$ [FPERF $=0]$} & -4.211 & 1.688 & 6.222 & 1 & .013 & -7.520 & -.902 \\
& {$[\mathrm{FPERF}=1]$} & -2.948 & 1.256 & 5.506 & 1 & .019 & -5.410 & -.486 \\
& {$[\mathrm{FPERF}=2]$} & 1.124 & 1.049 & 1.150 & 1 & .284 & -.931 & 3.179 \\
& {$[\mathrm{FPERF}=3]$} & 8.958 & 4.829 & 3.441 & 1 & .064 & -.507 & 18.423 \\
Location & ORGCO & -.106 & .045 & 5.431 & 1 & .020 & -.195 & -.017 \\
Scale & ORGCO & .024 & .012 & 3.679 & 1 & .055 & .000 & .048 \\
\hline
\end{tabular}

Link function: Negative Log-log.

\section{Conclusion and Recommendations}

The data and literature clearly supported the premise that organizational competitiveness positively influences the performance of manufacturing MSEs in Kenya. Firms that have the requisite organizational competitiveness possess the capacity to fulfill their obligations. The study points to the need for managing competencies to achieve better organizational competitiveness through simultaneous improvement in cost reduction, quality and innovativeness on an intra-firm and interfirm basis. Proactive firms initiate innovative changes to the organizational practices in cost reduction, and quality improvement to respond to cutthroat competition created by ever changing markets. Firms need know they cannot trend the growth path alone but only in a networked business ecosystem. Further research could help find answers to how the individual factors that formed the composite scales measuring organizational competitiveness influence firm performance. 


\section{References}

[1]. Allison, Paul. 1999. "Comparing Logit and Probit Coefficients Across Groups.” Sociological Methods and Research 28(2): 186208.

[2]. Barney, J.B. 1991, 'Firm resources and sustained competitive advantage', Journal of Management, vol. 17, no. 1, pp. 99-120.

[3]. Berry, A. (1997). SME Competitiveness: The Power of Networking and Subcontracting. Http://www.economia.gob.mx/pics/p/p2760/cipi_1LNetworking.pdf Access 18/09/2012

[4]. Chandler, G. N., \& Hanks, S. H. (1994). "Market attractiveness, resource-based capabilities, venture strategies, and venture performance". Journal of Business Venturing, 9, 331-349

[5]. Chong H 2008. Measuring performance of small-andmedium sized enterprises: The grounded theory approach. $J$ of Business and Public Affairs, 2(1): 1-10.

[6]. Churchill, G. A., \& Iacobucci, D. (2005). Marketing Research. Methodological Foundations (9th ed.). Australia, Canada, Mexico, Singapore, Spain, United Kingdom, United States: South-Western.

[7]. Cooper, D.R. \& Schindler, P.S. (2003). Business Research Methods. Boston: McGraw Hill.

[8]. Furlan, A., Grandinetti, R., \& Camuffo, A. (2007), "How do subcontractors evolve?" International Journal of Operations \& Production Management, Vol. 27 No. 1, 2007 pp 69-89.

[9]. George, D. \&Mallery, P. (2003). SPSS for Windows step by step: A simple guide and reference, 11.0 update (4 ${ }^{\text {th }}$ ed.). Boston: Alllyn\& Bacon.

[10]. Gierson, J. \& Mead, C. (1995). "Business linkages in Zimbabwe: Concept, Practice, Strategies", GEMINI working paper No. 49.

[11]. Grant, R.M. (2002). Contemporary Strategy Analysis, 4 edn, Blackwell Publishers Inc, Oxford.

[12]. Grossman, G. M. \& Helpman E. 2005. "Outsourcing in a Global Economy," Review of Economic Studies, Wiley Blackwell, vol. 72(1), pages $135-159,01$

[13]. Hair, J.F., Black, W.C., Babin, B.J., \& Anderson, R.E. (2010). Multivariate Data Analysis. Seventh Edition. Prentice Hall, Upper Saddle River, New Jersey.

[14]. Hoetker, G. 2007. The use of logit and probit models in strategic management research: Critical issues. Strategic Management Journal, 28(4):331-43.

[15]. Hu, Z., Zheng, J., \& Wang, J. (2011). 'Impact of industrial linkages on firm performance in Chinese development zones, Yangtze River Delta, Jiangsu Province, China', The Chinese Economy, vol. 44, no. 2, March-April 2011, pp. 78-105.

[16]. Kinyanjui, N.(2006). "The Case of KamukunjiJua Kali Metalwork Cluster in Nairobi, Kenya", a background study for the World Bank, 2006.

[17]. Locke, E. A., \& Latham, G. P. (2002). Buildingapracticallyusefultheoryofgoalsettingandtaskmotivation: A35-yearodyssey. American Psychologist. American Psychological Association.

[18]. Marimuthu M., Arokiasamy, L, \& Ismail, M. (2009). Human Capital Development And Its Impact On Firm Performance: Evidence From Developmental Economics. The Journal of International Social Research, Volume 2 / 8, Summer 2009, pp $265-272$.

[19]. McCullagh, P. (1980). Regression models for ordinal data. Journal of the Royal Statistical Society, Series B (Methodological), 42, $109-142$.

[20]. Mugenda, O. M. \& Mugenda, A. G., (2003), Research Methods; Quantitative and Qualitative Approaches, Acts Press, Nairobi, Kenya.

[21]. Norusis, J. M. (2012). IBM SPSS statistics 19.0 advanced statistical procedures companion. Upper Saddle River, NJ: Prentice Hall.

[22]. Ongong'a J. O. \& Abeka E. O. (2011). Networking in the Kenyan informal sector: An attempt to manage the market failures. African Journal of Business Management Vol. 5(28), pp. 11323-11334, 16 November, 2011

[23]. OECD (2004). Promoting entrepreneurship and innovative SMEs in a global economy: towards a more responsible and inclusive globalisation, 2nd OECD conference of ministers responsible for small and medium-sized enterprises (SMEs) Istanbul, Turkey 3-5 June 2004.

[24]. Porter, M.E. (1980). Competitive Strategy, Free Press, New York, 1980

[25]. Porter, M.E. (1985). Competitive Advantage, Free Press, New York, 1985

[26]. Smith, T. J. \& McKenna, C. ( 2012). "An Examination of Goodness-of-Fit Indices used in Ordinal Regression", Multiple Linear Regression Viewpoints, 2012, Vol. 38(1), 1-7

[27]. Tuan, N.P. \& Mai N.T. (2012). “A Firm Analysis Level of Supporting Industries in Hanoi City- Vietnam: Application of Resourcebased View and Industrial Organization. International Journal of Business Management, 7(5), 2012.

[28]. Tuan, N. P. \& Yoshi, T. (2010). Vertical Linkage and Firm's Performance in Supporting industries in Vietnam. Asian Journal of Management Research, 1(1), 1-14.

[29]. Tuan, N.P \& Takahashi, Y. (2009). Resources, Organizational Capabilities And Performance: Some Empirical Evidence From Vietnam's Supporting Industries, International Review of business Research Papers Vol. 5 No. 4 June 2009 Pp.219-231

[30]. Wang, C.K. \& Ang, B.L.(2004). 'Determinants of Venture Performance in Singapore', Journal of Small Business Management, vol. 42 , no. 4 , pp. $347-363$

[31]. Webster, M., Alder, C. \& Muhlemann A.P. (1997). Subcontracting within the supply chain for electronics assembly manufacture, in: International Journal of Operations \& Production Management, 17(9), pages 827-841, 1997.

[32]. Williams, R. (2009). Using heterogeneous choice models to compare logit and probit coefficients across groups. Sociological Methods and Research. 37 (4): 531-559 